\title{
Effect of Foliar Nutrients on Shoot Carbon and Nitrogen Content at Various Phenological Stages in Mango cv. Alphonso
}

\author{
K. V. Malshe*, S. S. Patil and P. M. Haldankar \\ Department of Horticulture, University of Agricultural Sciences, Dharwad, India \\ *Corresponding author
}

\begin{tabular}{|l|}
\hline Key w or d s \\
C : N ratio, \\
Alphonso, Mango, \\
Flowering \\
\hline Article Info \\
\hline Accepted: \\
22 December 2019 \\
Available Online: \\
20 January 2020 \\
\hline
\end{tabular}

\section{Keywords}

$\mathrm{C}: \mathrm{N}$ ratio,

Alphonso, Mango,

Flowering

Article Info

Accepted:

22 December 2019

20 January 2020

\section{A B S T R A C T}

The investigation was conducted at Department of Horticulture College of Agriculture, Dapoli, Dist. Ratnagiri, Maharashtra during the year 2015-16 and 2016-17 to assess the effect of foliar nutrition on post monsoon vegetative flush and flowering in mango cv. Alphonso. The experiment was laid out in Randomized Block Design with three replications and seven treatments viz; Urea$1 \%$, Potassium nitrate - $1 \%$, Orthophosphoric acid- $0.1 \%$, Urea-3\%, Potassium nitrate $-3 \%$, Orthophosphoric acid- $0.2 \%$ and control (No spray). Two sprays were taken in each treatment. $1^{\text {st }}$ spray immediately after emergences of new vegetative flush and second 15 days after first spray. The organic carbon content (in shoot), shoot nitrogen content and $\mathrm{C}: \mathrm{N}$ ratio were analyzed at three stages i.e. one month before flowering, during flowering and at one month after flowering by standard methods. One month before flowering, $\mathrm{KNO}_{3} 3 \%\left(\mathrm{~T}_{5}\right)$ treatment recorded significantly highest shoot carbon content (18.40 per cent), urea $3 \%\left(\mathrm{~T}_{4}\right)$ treatment recorded significantly highest shoot nitrogen content (1.457 per cent) and $\mathrm{KNO}_{3}$ $\left(\mathrm{T}_{5}\right)$ treatment recorded significantly highest $\mathrm{C}: \mathrm{N}$ ratio (13.35). During flowering, highest shoot carbon content (13.13 per cent) was in $\mathrm{KNO}_{3} 3 \%\left(\mathrm{~T}_{5}\right)$, shoot nitrogen content (1.246 per cent) was maximum in urea $3 \%\left(\mathrm{~T}_{4}\right)$ and highest $\mathrm{C}: \mathrm{N}$ ratio (10.63) was in $\mathrm{KNO}_{3} 3 \%\left(\mathrm{~T}_{5}\right)$. At one month after flowering, the significantly highest shoot carbon content (15.33 per cent) was recorded in $\mathrm{KNO}_{3} 3 \%\left(\mathrm{~T}_{5}\right)$ treatment, highest shoot nitrogen content $\left(1.135\right.$ per cent) was in urea $3 \%\left(\mathrm{~T}_{4}\right)$ treatment and highest $\mathrm{C}: \mathrm{N}$ ratio (10.63) was recorded in $\mathrm{KNO}_{3} 3 \%\left(\mathrm{~T}_{5}\right)$ treatment.

\section{Introduction}

Mango (Mangifera indica L.) unanimously considered as the choicest tropical fruit of the world. It is the national fruit of India and known as King of the fruits'. It has originated from South East Asia, the Indo-Burma region, in the foothills of the Himalayas (Mukherjee, 1951). Mango is the main commercial fruit crop of our country. It is the third widely produced fruit crops of the tropics after banana and citrus. It has been variously called 
Amra, Chuta, Rasala, Sahakara, Atisourabha, in ancient Sanskrit literature, and the tree has been described as Kalpa-Vriksha, or the wishgranting tree.

The total world production of mango is 465.07 lakh tonnes (Anon., 2017). It is commercially grown in more than 111 countries but nowhere it is greatly valued as in India where 40 per cent of area under mango. India is the major mango producer in the world, with an area of 2.263 million ha and the annual production of 19.687 million tonnes with productivity of $8.7 \mathrm{MT} / \mathrm{ha}$ (Anon., 2017). India contributes about 64 per cent of the world mango production. Other mango producing countries are Mexico, Pakistan, Brazil, Philippines and Thailand. India has rich wealth of mango germplasm with more than 1000 varieties growing throughout the country. Among them, Alphonso tops the list and is grown along the west coast of India; Maharashtra, Goa, Karnataka and Gujarat which is acclaimed as one of the best Indian mango variety.

Konkan is the major and famous mango producing region on the west coast of Maharashtra comprising of Palghar, Thane, Raigad, Ratnagiri and Sindhudurg district is famous for the production of quality mangoes. This region is emerging as one of the largest mango growing belts in country. In Konkan about $90 \%$ area under mango is occupied by single cultivar "Alphonso", which is locally called as "Hapus". It thrives and yield best under warm and humid climate of Konkan region. It is specially preferred for export because of its delicious taste exceeding acceptable flavor, attractive colour and exemplary nutritive value.

It is best for table and processing purpose (Cheema and Dhani, 1934). The warm and humid climate throughout the year and rain free season from November to May prevalent in Konkan region is ideal for mango in general and Alphonso in particular. It enjoys virtual dominance both in domestics as well as in international markets due to its typical sugar-acid blend, pleasant aroma, highly appreciable flavour and taste because of which farmers are getting premium prices.

The phenomenon of flowering and fruiting in mango is complex. A conceptual flowering model has been described to explain the interaction of internal and external factors regulating vegetative and reproductive shoot initiation and induction in mango trees growing in tropical and subtropical environments (Davenport and Nunez-Elisea, 1997). Mango flowering is predominantly influenced by the biochemical constituents present in the phase for the floral stimuli at bud break stage. The maturity of terminal shoot and accumulation of carbohydrate in the leaves and shoot apex are in some way associated with the synthesis of the floral stimulus in mango trees (Kumar et al., 2013).

The improvement in productivity in modern agriculture system is increasingly dependent on manipulation of the physiological activities of the crop by chemical means. In commercial mango plantations, it is desirable to control the vegetative growth to get uniform and regular flowering (Anon., 2013).

The important reason for low productivity of Alphonso mango is the alternate bearing habit. In Alphonso, the twig which induces flowering is about 8-9 month age. Mature twig produces flowering especially in Alphonso mango. The induction of early flowering results in early maturity of fruits and such fruit fetches higher prices in the market as compared to late maturing fruits. Weather during initiation of flowering in the month of September and October play a key role in induction of the flowering at appropriate time. Generally, after monsoon 
when the rainfall ceases and dry spell commences, the flowering occurs in mango from October November. Instead of cessation in the month of September, the monsoon delayed even up to November. The temperature increases considerably after monsoon before winter. Due to such climatic abbreviations, instead of flowering the plant produces vegetative flush. Furthermore, it is often noticed that many of these new shoots do not produce flowers and hence the flowering is spared which result in poor yield. It is therefore necessary to control the new vegetative growth after monsoon so as to induce timely flowering. Similarly, it is also necessary to hasten the maturity of newly produced vegetative shoots so that it will produce early flowering.

The nutrients play important role in plant metabolism, growth and developmental processes and help in increasing biomass production and yield. Plant nutrient studies have focused attention upon significance of nitrogen particularly in fruit crops where it can influence various enzymatic and physiological process and phenomenal increase in productivity has been achieved where specific nutrients particularly nitrogen in the form of urea and thio-urea through foliar feeding are applied. Potassium nitrate $\left(\mathrm{KNO}_{3}\right)$, also known as nitric acid is considered a specially fertilizer. It is a colourless transparent crystal or white powder with $14 \%$ nitrogen $(\mathrm{N})$ and $46 \%$ potassium $(\mathrm{K}) . \mathrm{KNO}_{3}$ is one of the chemical inducing substance that has shown some potential for nitrate reductive and stimulating the production of ethylene. Phosphorous chemicals like Ortho-phosphoric acid $\left(\mathrm{KH}_{2} \mathrm{PO}_{4}\right)$ and Phosphoric acid $\left(\mathrm{H}_{3} \mathrm{PO}_{4}\right)$ helps in enhancing the flowering because phosphorus has been reported to be an important component of energy transduction mechanisms.
Singh (1960) demonstrated that initiation of flowering mainly depends on maintenance of higher $\mathrm{C} / \mathrm{N}$ ratio. Corbesier et al., (2002) reported that the high endogenous ratio of carbon to nitrogen ratio in plants is stimulatory to flowering whereas a low $\mathrm{C}: \mathrm{N}$ ratio favours vegetative growth. In mango, Sudha et al., (2012) reported that $\mathrm{C} / \mathrm{N}$ ratio in mango leaves was highest with $\mathrm{KNO}_{3} 2 \%$ (10.1), and lowest in control (10.1). Highest carbohydrate content was observed in trees sprayed with $\quad \mathrm{KNO}_{3} \quad 2 \% \quad\left(\begin{array}{lll}14.5 \mathrm{~g} & 100 \mathrm{~g}^{-1}\end{array}\right)$ compared to control $\left(11.0 \mathrm{~g} 100 \mathrm{~g}^{-1}\right)$. Plants sprayed with $2 \% \quad \mathrm{KNO}_{3}$ registered higher nitrogen content $(1.4 \%)$ than the control $(1.0 \%)$.

The $\mathrm{C}: \mathrm{N}$ ratio plays a vital role in mango flowering and foliar nutrition influence the carbon and nitrogen content in the shoots and become the key factor for induction of flowering. Therefore to assess the impact, an investigation on "Effect of foliar nutrients on carbon and nitrogen content in shoot of mango cv. Alphonso was carried out.

\section{Materials and Methods}

The present investigation was conducted at Department of Horticulture College of Agriculture, Dapoli, Dist. Ratnagiri, Maharashtra during the year 2015-16 and 2016-17 to assess the effect of foliar nutrition on post monsoon vegetative flush and flowering in mango cv. Alphonso. In 35 years old mango orchard and uniformly growing mango trees were selected for experimentation. The experiment was laid out in Randomized Block Design with three replications and seven treatments viz., Urea$1 \%$, Potassium nitrate - 1\%, Orthophosphoric acid- $0.1 \%$, Urea-3\%, Potassium nitrate $-3 \%$, Orthophosphoric acid- $0.2 \%$ and control (No spray). The recommended cultivation practices were carried out to manage the experimental plot. Two sprays were taken in 
each treatment. $1^{\text {st }}$ spray immediately after emergences of new vegetative flush and second 15 days after first spray. The organic carbon content (in shoot), shoot nitrogen content and $\mathrm{C}: \mathrm{N}$ ratio were analyzed at three stages i.e. one month before flowering, during flowering and at one month after flowering by standard methods. The $\mathrm{C}: \mathrm{N}$ ratio of the selected shoots was calculated by the ratio of estimated carbon per cent to the estimated total nitrogen per cent of respective shoot. The experimental data were analyzed according the procedure described by Panse and Sukhatme (1985).

\section{Results and Discussion}

The data pertaining to shoot organic carbon content, shoot nitrogen content and $\mathrm{C}: \mathrm{N}$ ratio were recorded at three stages i.e. one month before flowering, during flowering and at one month after flowering and presented in Table 1 to 3 .

\section{Shoot carbon content}

The data presented in Table 1 indicated that, the carbon content of terminal shoots examined at different stages of flowering varied significantly among the treatments in both the years. Data further revealed that irrespective of nutrient treatments, the shoot carbon content decreased from one month before flowering stage to during flowering then increased to one month after flowering.

\section{Shoot carbon content at one month before flowering}

In the first year of experiment, the highest shoot carbon content (18.32 per cent) was recorded in $\mathrm{KNO}_{3} 3 \%\left(\mathrm{~T}_{5}\right)$ treatment and it was on par with $\mathrm{KNO}_{3} \quad 1 \%\left(\mathrm{~T}_{2}\right)$ treatment. The lowest shoot carbon content (13.52 per cent) was in control $\left(\mathrm{T}_{7}\right)$. However, the rest of nutrient treatments were on par among themselves.
In second year, similar trend was noticed. Amongst the various treatments, significantly highest shoot carbon content (18.49 per cent) was recorded in $\mathrm{KNO}_{3} 3 \%\left(\mathrm{~T}_{5}\right)$ treatment and it was on par with $\mathrm{KNO}_{3} 1 \%$ (18.29 per cent) and urea 3\% (17.90 per cent) treatments. $\mathrm{H}_{3} \mathrm{PO}_{4} 0.1$ and $0.2 \%$ and urea $1 \%$ treatments were exhibited highest shoot carbon content almost on same bar. The lowest shoot carbon content (13.42 per cent) was in control $\left(\mathrm{T}_{7}\right)$.

The pooled data indicated that $\mathrm{KNO}_{3} 3 \%\left(\mathrm{~T}_{5}\right)$ treatment recorded significantly highest shoot carbon content (18.40 per cent) and closely followed by $\mathrm{KNO}_{3} 1 \%$ (18.21 per cent). The shoot carbon content was lowest (13.47 per cent) in control $\left(\mathrm{T}_{7}\right)$.

\section{Shoot carbon content during flowering}

In the first year, the significantly highest shoot carbon content during flowering (13.17 per cent) was recorded in $\mathrm{KNO}_{3} \quad 3 \%\left(\mathrm{~T}_{5}\right)$ treatment and it was on par with rest of the nutrient treatments except $\mathrm{H}_{3} \mathrm{PO}_{4} \quad 0.2 \%$ treatment. The lowest shoot carbon content during flowering (11.31 per cent) was in control $\left(\mathrm{T}_{7}\right)$.

In second year, significantly highest shoot carbon content (13.09 per cent) was recorded again in $\mathrm{KNO}_{3} 3 \%\left(\mathrm{~T}_{5}\right)$ treatment and it was on par with rest of nutrient treatments. The lowest shoot carbon content (11.06 per cent) was in control $\left(\mathrm{T}_{7}\right)$.

From the pooled data it revealed that during the flowering, shoot carbon content was significantly increased due to nutrient treatments. The significantly highest shoot carbon content (13.13 per cent) was recorded in $\mathrm{KNO}_{3} 3 \%\left(\mathrm{~T}_{5}\right)$ treatment and this value was on par with rest of the treatments. The shoot carbon content was lowest (11.18 per cent) in control $\left(\mathrm{T}_{7}\right)$. 


\section{Shoot carbon content at one month after flowering}

In the first year of experiment, the highest shoot carbon content at one month after flowering (15.31 per cent) was recorded in $\mathrm{KNO}_{3} 3 \%\left(\mathrm{~T}_{5}\right)$ treatment and it was closely followed by $\mathrm{T}_{2}\left(15.16\right.$ per cent) and $\mathrm{T}_{6}(15.00$ per cent) treatments. The lowest shoot carbon content (13.85 per cent) was in control $\left(\mathrm{T}_{7}\right)$ followed by urea treatments as $\mathrm{T}_{1}$ (13.91 per cent) and $\mathrm{T}_{4}(14.40$ per cent $)$.

In the second year, at one month after flowering, significantly highest shoot carbon content (15.34 per cent) was recorded again in $\mathrm{KNO}_{3} 3 \%\left(\mathrm{~T}_{5}\right)$ treatment followed by $\mathrm{KNO}_{3}$ $1 \%\left(\mathrm{~T}_{2}\right)$ which was on par with nutrient treatments except urea $1 \%$ treatment. The lowest shoot carbon content (13.00 per cent) was in control $\left(\mathrm{T}_{7}\right)$.

The pooled data exhibited similar trend. At one month after flowering, the significantly highest shoot carbon content (15.33 per cent) was recorded in $\mathrm{KNO}_{3} 3 \%\left(\mathrm{~T}_{5}\right)$ treatment and it was on par with $\mathrm{KNO}_{3} 1 \%\left(\mathrm{~T}_{2}\right)$ and $\mathrm{H}_{3} \mathrm{PO}_{4}$ $0.2 \%$ and $0.1 \%$ treatments. The shoot carbon content was lowest (13.42 per cent) in control $\left(\mathrm{T}_{7}\right)$.

\section{Shoot nitrogen content}

The data regarding the changes in shoot nitrogen content from one month before flowering to one month after flowering were presented in Table 2. From the data, it revealed that the nitrogen content of terminal shoots at different flowering stages varied significantly among the treatments in both the years. Irrespective of nutrient treatments, the shoot nitrogen content sudden decreased from one month before flowering stage to during flowering then gradually decreased to one month after flowering.

\section{Shoot nitrogen content at one month before flowering}

In the first year of experiment, the highest shoot nitrogen content (1.450 per cent) was recorded in urea 3\% $\left(\mathrm{T}_{4}\right)$ treatment and it was on par with urea $1 \%\left(\mathrm{~T}_{1}\right)$ treatment (1.445). It was followed by $\mathrm{KNO}_{3}$ treatments and $\mathrm{H}_{3} \mathrm{PO}_{4}$ treatments. The lowest shoot nitrogen content (1.307 per cent) was in control $\left(\mathrm{T}_{7}\right)$.

In second year, significantly highest shoot nitrogen content (1.464 per cent) was recorded in urea $3 \%\left(\mathrm{~T}_{4}\right)$ treatment and it was closely followed with urea $1 \%\left(\mathrm{~T}_{1}\right)$.

The reset of the nutrient treatments were on par among themselves. The lowest shoot nitrogen content (1.296 per cent) was in control $\left(\mathrm{T}_{7}\right)$.

The pooled data indicated that urea 3\% $\left(\mathrm{T}_{4}\right)$ treatment recorded significantly highest shoot nitrogen content (1.457 per cent) at one month before flowering and closely followed by urea $1 \%$ ( 1.445 per cent). The shoot nitrogen content was lowest (1.302 per cent) in control $\left(\mathrm{T}_{7}\right)$.

\section{Shoot nitrogen content during flowering}

In the first year, the significantly highest shoot nitrogen content during flowering (1.247 per cent) was recorded in urea $3 \%\left(\mathrm{~T}_{4}\right)$ treatment and it was on par with rest of the nutrient treatments. The lowest shoot nitrogen content (1.153 per cent) was in control $\left(\mathrm{T}_{7}\right)$.

In second year, significantly highest shoot nitrogen content (1.245 per cent) was recorded again in urea $3 \%\left(\mathrm{~T}_{4}\right)$ treatment and it was on par with urea $1 \%$ (1.237per cent) and $\mathrm{KNO}_{3} 3 \%$ (1.235 per cent). The lowest shoot nitrogen content (1.159 per cent) was in control $\left(\mathrm{T}_{7}\right)$ followed by $\mathrm{H}_{3} \mathrm{PO}_{4} 0.2 \%$ (1.196 per cent). 
From the pooled data it revealed that during the flowering, the significantly highest shoot nitrogen content (1.246 per cent) was recorded in urea 3\% $\left(\mathrm{T}_{4}\right)$ treatment and it was on par with $\mathrm{T}_{1}, \mathrm{~T}_{5}$ and $\mathrm{T}_{2}$ treatments. The shoot nitrogen content was relatively less in $\mathrm{H}_{3} \mathrm{PO}_{4}$ treatments. The shoot carbon content was lowest (1.156 per cent) in control $\left(\mathrm{T}_{7}\right)$.

\section{Shoot nitrogen content at one month after flowering}

In the first year of experiment, the highest shoot nitrogen content at one month after flowering (1.131 per cent) was recorded in urea $3 \%\left(\mathrm{~T}_{4}\right)$ treatment and it was closely followed by $\mathrm{T}_{1}$ (1.125 per cent), $\mathrm{T}_{5}$ (1.123 per cent) and $\mathrm{T}_{2}$ (1.122 per cent) treatments. The shoot nitrogen content in $\mathrm{H}_{3} \mathrm{PO}_{4}$ treatments did not influenced relatively and on par with control $\left(\mathrm{T}_{7}\right)$ having 1.113 per cent shoot nitrogen content.

In the second year, at one month after flowering, highest shoot nitrogen content (1.138 per cent) was again recorded in urea $3 \%\left(\mathrm{~T}_{4}\right)$ treatment and it was on par with urea $1 \%\left(\mathrm{~T}_{1}\right)$. The rest of nutrient treatments were on par with each other. The lowest shoot nitrogen content (1.056 per cent) was in control $\left(\mathrm{T}_{7}\right)$.

The pooled data exhibited that the significantly highest shoot nitrogen content at one month after flowering (1.135 per cent) was recorded in urea $3 \%\left(\mathrm{~T}_{4}\right)$ treatment. The urea $1 \%\left(\mathrm{~T}_{1}\right)$ and $\mathrm{KNO}_{3}$ treatments $\left(\mathrm{T}_{5}\right.$ and $\mathrm{T}_{2}$ ) were on par among themselves. $\mathrm{H}_{3} \mathrm{PO}_{4} 0.1$ $\%$ and $0.2 \%\left(\mathrm{~T}_{3}\right.$ and $\left.\mathrm{T}_{6}\right)$ treatments had 1.112 per cent shoot nitrogen content. The shoot nitrogen content was lowest (1.085 per cent) in control $\left(\mathrm{T}_{7}\right)$.

\section{Shoot $\mathbf{C}: \mathbf{N}$ ratio}

The data regarding $\mathrm{C}: \mathrm{N}$ ratio estimated at three different stages are presented in Table 3.
It is revealed that the $\mathrm{C}: \mathrm{N}$ ratio in the nutrient treatments were significantly improved over control. Irrespective of the treatments the $\mathrm{C}: \mathrm{N}$ ratio was declined from one month before flowering stage to flowering and increased at one month after flowering.

\section{$\mathrm{C}: \mathrm{N}$ ratio at one month before flowering}

In the first year of experiment, the significantly highest $\mathrm{C}: \mathrm{N}$ ratio (13.25) was recorded by the treatment $\mathrm{KNO}_{3} 3 \%\left(\mathrm{~T}_{5}\right)$ which was on par with $\mathrm{KNO}_{3} 1 \%$ treatment $\left(\mathrm{T}_{2}\right)$ treatment (13.24). The urea and $\mathrm{H}_{3} \mathrm{PO}_{4}$ treatments exhibited $\mathrm{C}: \mathrm{N}$ ratio on par among themselves levels. The lowest $\mathrm{C}: \mathrm{N}$ ratio (10.34) was in control $\left(\mathrm{T}_{7}\right)$.

In second year, similar trend was noticed. The highest $\mathrm{C}: \mathrm{N}$ ratio (13.44) was recorded in $\mathrm{KNO}_{3}$ treatments $\left(\mathrm{T}_{5}\right)$ treatment and it was closely followed by $\mathrm{KNO}_{3} 1 \%$ treatment $\left(\mathrm{T}_{2}\right)$. The lowest $\mathrm{C}: \mathrm{N}$ ratio (10.36) was in control $\left(\mathrm{T}_{7}\right)$.

The pooled data indicated that $\mathrm{KNO}_{3}\left(\mathrm{~T}_{5}\right)$ treatment recorded significantly highest $\mathrm{C}: \mathrm{N}$ ratio (13.35) at one month before flowering and closely followed by $\mathrm{KNO}_{3} 1 \%$ treatment (13.28). The $\mathrm{C}: \mathrm{N}$ ratio was lowest (10.35) in control $\left(\mathrm{T}_{7}\right)$. The $\mathrm{KNO}_{3}$ treatments were followed by $\mathrm{H}_{3} \mathrm{PO}_{4} 0.2 \%$ and $0.1 \%$ (12.72 and 12.45 , respectively). The $\mathrm{C}: \mathrm{N}$ ratio was 11.80 and 11.70 in urea $3 \%$ and $1 \%$ treatments, respectively.

\section{$\mathrm{C}: \mathrm{N}$ ratio during flowering}

During the flowering, the $\mathrm{C}: \mathrm{N}$ ratio was significantly influenced due to foliar nutrient spray. In the first year, the significantly highest $\mathrm{C}$ : $\mathrm{N}$ ratio during flowering (10.66) was recorded in $\mathrm{KNO}_{3} 3 \%\left(\mathrm{~T}_{5}\right)$ treatment and it was on par with $\mathrm{H}_{3} \mathrm{PO}_{4} 0.1 \%$ (10.64), $\mathrm{KNO}_{3}$ $1 \%$ (10.49) and $\mathrm{H}_{3} \mathrm{PO}_{4} 0.2 \%$ (10.40). The lowest $\mathrm{C}: \mathrm{N}$ ratio $(9.80)$ was in control $\left(\mathrm{T}_{7}\right)$. 
In second year, significantly $\mathrm{C}$ : $\mathrm{N}$ ratio (10.60) was recorded again in $\mathrm{KNO}_{3}\left(\mathrm{~T}_{5}\right)$ treatment and it was on par with rest of the treatments. The lowest $\mathrm{C}: \mathrm{N}$ ratio (9.54) was in control $\left(\mathrm{T}_{7}\right)$.

The pooled data revealed that during the flowering, the significantly highest $\mathrm{C}: \mathrm{N}$ ratio (10.63) was recorded in $\mathrm{KNO}_{3} \quad 3 \% \quad\left(\mathrm{~T}_{5}\right)$ treatment and it was on par with $\mathrm{H}_{3} \mathrm{PO}_{4} 0.1 \%$ (10.62) and $\mathrm{KNO}_{3} 1 \%$ (10.53). The shoot nitrogen content was relatively less in urea treatments. The $\mathrm{C}: \mathrm{N}$ ratio was lowest (9.67) in control.

\section{$\mathrm{C}: \mathrm{N}$ ratio at one month after flowering}

In the first year of experiment, the highest $\mathrm{C}$ : $\mathrm{N}$ ratio at one month after flowering (13.63) was recorded in $\mathrm{KNO}_{3} 3 \%\left(\mathrm{~T}_{5}\right)$ treatment and it was on par with rest of the $\mathrm{KNO}_{3}$ and $\mathrm{H}_{3} \mathrm{PO}_{4}$ treatments. However, the $\mathrm{C}: \mathrm{N}$ ratio was lowest in urea $1 \%\left(\mathrm{~T}_{1}\right)$ treatment followed by control (12.44).

In the second year, at one month after flowering, highest $\mathrm{C}: \mathrm{N}$ ratio (13.71) was again recorded by the treatment $\mathrm{KNO}_{3} 3 \%$ $\left(\mathrm{T}_{5}\right)$ and it was followed by $\mathrm{KNO}_{3} 1 \%$ (13.42). The lowest $\mathrm{C}: \mathrm{N}$ ratio (12.30) was in control $\left(\mathrm{T}_{7}\right)$. The treatments of $\mathrm{H}_{3} \mathrm{PO}_{4}(0.1$ and 0.2 per cent) and urea ( 1 and 3 per cent) were on par among their levels.

The pooled data exhibited that the significantly highest $\mathrm{C}: \mathrm{N}$ ratio at one month after flowering (13.67) was recorded in $\mathrm{KNO}_{3}$ $3 \%\left(\mathrm{~T}_{5}\right)$ treatment. It was followed by $\mathrm{T}_{2}$ (13.46), $\mathrm{T}_{6}$ (13.37) and $\mathrm{T}_{3}$ (13.32). The $\mathrm{C}: \mathrm{N}$ ratio was lowest (12.37) in control $\left(\mathrm{T}_{7}\right)$. The urea treatments had fairly higher $\mathrm{C}: \mathrm{N}$ ratio than control.

In the present study, the periodical shoot carbon and nitrogen content in Alphonso mango (One month before flowering, during flowering and one month after flowering) was analyzed to assess the influence of foliar sprays of nutrients. The foliar nutrition increased shoot carbon, nitrogen content and $\mathrm{C}: \mathrm{N}$ ratio than control.

Irrespective of foliar nutrition treatments, the shoot carbon content decreased from one month before flowering stage to during flowering then increased to one month after flowering. Consequently, the shoot nitrogen content hasty decreased from one month before flowering stage to during flowering then steadily decreased to one month after flowering.

The shoot carbon content at all three stages was found highest in $\mathrm{KNO}_{3} 3 \%$ treatment (18.40 per cent at one month before flowering, 13.13 per cent during flowering and 15.33 per cent at one month after flowering). $\mathrm{KNO}_{3} 1 \%$ was found as second best treatment for shoot carbon content. In case of shoot nitrogen, urea 3\% treatment recorded significantly highest content (1.457 per cent at one month before flowering, 1.246 per cent during flowering and 1.135 per cent at one month after flowering).

As regards to $\mathrm{C}: \mathrm{N}$ ratio, $\left(\mathrm{KNO}_{3} 3 \%\right.$ treatment exhibited highest $\mathrm{C}: \mathrm{N}$ ratio $(13.35$ at one month before flowering, 10.63 during flowering and 13.67 at one month after flowering. As $\mathrm{C}: \mathrm{N}$ ratio is derived from the shoot carbon and nitrogen content, the variation in these values are due to proportion.

The trend of $\mathrm{C}: \mathrm{N}$ ratio was found to be same as that of carbon content. The similar finding was also noticed by Rakshe (2011) in Alphonso mango. The decline of nitrogen content during various stages was also reported by Pathak and Pandey (1978) and Patil (2009). 
Table.1 Effect of foliar application of nutrients on shoot carbon content at different stages in mango cv. Alphonso

\begin{tabular}{|c|c|c|c|c|c|c|c|c|c|}
\hline \multirow[t]{3}{*}{ Treatments } & \multicolumn{9}{|c|}{ Shoot Carbon Content (\%) } \\
\hline & \multicolumn{3}{|c|}{$\begin{array}{l}\text { One month before } \\
\text { flowering }\end{array}$} & \multicolumn{3}{|c|}{ During flowering } & \multicolumn{3}{|c|}{$\begin{array}{l}\text { One month after } \\
\text { flowering }\end{array}$} \\
\hline & 2015 & 2016 & $\begin{array}{c}\text { Pooled } \\
\text { mean }\end{array}$ & 2015 & 2016 & $\begin{array}{c}\text { Pooled } \\
\text { mean }\end{array}$ & 2015 & 2016 & $\begin{array}{c}\text { Pooled } \\
\text { mean }\end{array}$ \\
\hline$T_{1}:$ Urea-1\% & 16.98 & 16.83 & 16.91 & 12.81 & 12.69 & 12.75 & 13.91 & 14.36 & 14.13 \\
\hline $\mathrm{T}_{2}$ : Potassium nitrate - $1 \%$ & 18.12 & 18.29 & 18.21 & 12.93 & 12.89 & 12.91 & 15.16 & 14.99 & 15.07 \\
\hline $\begin{array}{l}\text { T }_{3} \text { : Orthophosphoric acid- } \\
0.1 \%\end{array}$ & 16.79 & 16.74 & 16.77 & 12.96 & 12.92 & 12.94 & 14.89 & 14.71 & 14.80 \\
\hline $\mathbf{T}_{4}:$ Urea-3\% & 16.50 & 17.90 & 17.20 & 12.79 & 12.80 & 12.80 & 14.40 & 14.56 & 14.48 \\
\hline $\mathrm{T}_{5}$ : Potassium nitrate - $3 \%$ & 18.32 & 18.49 & 18.40 & 13.17 & 13.09 & 13.13 & 15.31 & 15.34 & 15.33 \\
\hline $\begin{array}{l}\text { T }_{6}: \text { Orthophosphoric acid- } \\
0.2 \%\end{array}$ & 17.14 & 17.19 & 17.16 & 12.39 & 12.58 & 12.49 & 15.00 & 14.74 & 14.87 \\
\hline $\mathbf{T}_{7}:$ Control & 13.52 & 13.42 & 13.47 & 11.31 & 11.06 & 11.18 & 13.85 & 13.00 & 13.42 \\
\hline SE M \pm & 0.234 & 0.278 & 0.181 & 0.185 & 0.210 & 0.140 & 0.185 & 0.226 & 0.146 \\
\hline C.D. (at 5\%) & 0.720 & 0.856 & 0.530 & 0.569 & 0.647 & 0.408 & 0.569 & 0.696 & 0.426 \\
\hline
\end{tabular}


Table.2 Effect of foliar application of nutrients on shoot nitrogen content at different stages in mango cv. Alphonso

\begin{tabular}{|c|c|c|c|c|c|c|c|c|c|}
\hline \multirow[t]{3}{*}{ Treatments } & \multicolumn{9}{|c|}{ Shoot Nitrogen Content (\%) } \\
\hline & \multicolumn{3}{|c|}{$\begin{array}{l}\text { One month before } \\
\text { flowering }\end{array}$} & \multicolumn{3}{|c|}{ During flowering } & \multicolumn{3}{|c|}{$\begin{array}{l}\text { One month after } \\
\text { flowering }\end{array}$} \\
\hline & 2015 & 2016 & $\begin{array}{c}\text { Pooled } \\
\text { mean }\end{array}$ & 2015 & 2016 & $\begin{array}{c}\text { Pooled } \\
\text { mean }\end{array}$ & 2015 & 2016 & $\begin{array}{c}\text { Pooled } \\
\text { mean }\end{array}$ \\
\hline $\mathrm{T}_{1}:$ Urea-1\% & 1.447 & 1.442 & 1.445 & 1.238 & 1.236 & 1.237 & 1.125 & 1.123 & 1.124 \\
\hline$T_{2}:$ Potassium nitrate $-1 \%$ & 1.369 & 1.373 & 1.371 & 1.233 & 1.220 & 1.227 & 1.122 & 1.117 & 1.120 \\
\hline$T_{3}:$ Orthophosphoric acid- $0.1 \%$ & 1.350 & 1.344 & 1.347 & 1.218 & 1.220 & 1.219 & 1.114 & 1.109 & 1.112 \\
\hline $\mathbf{T}_{4}:$ Urea-3\% & 1.450 & 1.464 & 1.457 & 1.247 & 1.245 & 1.246 & 1.131 & 1.138 & 1.135 \\
\hline$T_{5}:$ Potassium nitrate - 3\% & 1.382 & 1.376 & 1.379 & 1.235 & 1.235 & 1.235 & 1.123 & 1.119 & 1.121 \\
\hline $\mathrm{T}_{6}:$ Orthophosphoric acid- $0.2 \%$ & 1.342 & 1.358 & 1.350 & 1.191 & 1.196 & 1.194 & 1.115 & 1.110 & 1.112 \\
\hline $\mathbf{T}_{7}:$ Control & 1.307 & 1.296 & 1.302 & 1.153 & 1.159 & 1.156 & 1.113 & 1.056 & 1.085 \\
\hline $\mathbf{S E} \mathbf{M} \pm$ & 0.009 & 0.020 & 0.011 & 0.009 & 0.011 & 0.007 & 0.004 & 0.012 & 0.003 \\
\hline C.D. (at 5\%) & 0.029 & 0.060 & 0.032 & 0.0277 & 0.035 & 0.021 & 0.013 & 0.036 & 0.008 \\
\hline
\end{tabular}


Table.3 Effect of foliar application of nutrients on $\mathrm{C}: \mathrm{N}$ ratio at different stages in mango cv. Alphonso

\begin{tabular}{|c|c|c|c|c|c|c|c|c|c|}
\hline \multirow[t]{3}{*}{ Treatments } & \multicolumn{9}{|c|}{ C : N Ratio } \\
\hline & \multicolumn{3}{|c|}{$\begin{array}{l}\text { One month before } \\
\text { flowering }\end{array}$} & \multicolumn{3}{|c|}{ During flowering } & \multicolumn{3}{|c|}{$\begin{array}{l}\text { One month after } \\
\text { flowering }\end{array}$} \\
\hline & 2015 & 2016 & $\begin{array}{c}\text { Pooled } \\
\text { mean }\end{array}$ & 2015 & 2016 & $\begin{array}{c}\text { Pooled } \\
\text { mean }\end{array}$ & 2015 & 2016 & $\begin{array}{c}\text { Pooled } \\
\text { mean }\end{array}$ \\
\hline$T_{1}:$ Urea-1\% & 11.74 & 11.67 & 11.70 & 10.35 & 10.26 & 10.31 & 12.36 & 12.79 & 12.57 \\
\hline $\mathrm{T}_{2}:$ Potassium nitrate $-1 \%$ & 13.24 & 13.32 & 13.28 & 10.49 & 10.56 & 10.53 & 13.51 & 13.42 & 13.46 \\
\hline $\mathrm{T}_{3}$ : Orthophosphoric acid- $0.1 \%$ & 12.44 & 12.46 & 12.45 & 10.64 & 10.59 & 10.62 & 13.37 & 13.26 & 13.32 \\
\hline $\mathrm{T}_{4}:$ Urea-3\% & 11.38 & 12.22 & 11.80 & 10.26 & 10.29 & 10.27 & 12.73 & 12.79 & 12.76 \\
\hline $\mathrm{T}_{5}:$ Potassium nitrate $-\mathbf{3 \%}$ & 13.25 & 13.44 & 13.35 & 10.66 & 10.60 & 10.63 & 13.63 & 13.71 & 13.67 \\
\hline $\mathrm{T}_{6}:$ Orthophosphoric acid- $0.2 \%$ & 12.77 & 12.66 & 12.72 & 10.40 & 10.52 & 10.46 & 13.45 & 13.28 & 13.37 \\
\hline $\mathbf{T}_{7}:$ Control & 10.34 & 10.36 & 10.35 & 9.80 & 9.54 & 9.67 & 12.44 & 12.30 & 12.37 \\
\hline $\mathbf{S E} \mathbf{M} \pm$ & 0.15 & 0.15 & 0.11 & 0.10 & 0.11 & 0.07 & 0.14 & 0.11 & 0.09 \\
\hline C.D. (at 5\%) & 0.46 & 0.48 & 0.32 & 0.32 & 0.33 & 0.22 & 0.44 & 0.34 & 0.26 \\
\hline
\end{tabular}


An earlier reports also indicated that there was a decrease in $\mathrm{C}: \mathrm{N}$ ratio at latter stages in mango (Sen and Mallick, 1941), which could be attributed to transformation of vegetative phase into reproductive phase in mango which requires energy. This energy is derived from the various metabolic activities in the shoots. Mainly, polysaccharides, which are stored in the shoots, may undergoes amylolytic hydrolysis to provide chemical energy which will be utilized in differentiation process. Similar findings in regards to variation in $\mathrm{C}: \mathrm{N}$ ratio was also reported by Ravishankar and Rao (1982) who noted that $\mathrm{C}: \mathrm{N}$ ratio was low in Alphonso mango before flowering.

Among the various foliar nutrient treatments tried to hasten the maturity of post monsoon vegetative flush of mango, potassium nitrate @ $3 \%$ found to be the best treatment as it content potassium with nitrogen and its supplementary nutrition altered the carbon content and consequently $\mathrm{C}: \mathrm{N}$ ratio. In urea treatments, shoot nitrogen content was higher but carbon content was low and had proportionately low $\mathrm{C}$ : $\mathrm{N}$ ratio. Potassium nitrate possibly acts by elevating nitrogen levels over a nitrogen threshold thereby synchronizing bud break from apices with existing floral initials. The signaling process is possibly meditated by polyamines or ethylene (Protacio, 2000). High $\mathrm{C} / \mathrm{N}$ ratio was probably conducive to floral induction and in present investigation potassium nitrate found beneficial for improve flowering, fruit set and yield in mango cv. Alphonso, rather than use of urea, $\mathrm{H}_{3} \mathrm{PO}_{4}$.

The findings of present study were in conformity with the findings reported by Sarkar et al., (2005) and Sudha et al., (2012) in mango.

It is inferred that the post monsoon foliar spray of potassium nitrate $\left(\mathrm{KNO}_{3}\right) @ 3 \%$ was found superior to improve the $\mathrm{C}$ : $\mathrm{N}$ ratio prior to flowering which is beneficial for the bud break and induction of flowering in mango cv. Alponso.

\section{References}

Anonymous, 2013. Mango production technology. Pub. Dr. B. S. Konkan Krishi Vidyapeeth, Dapoli.

Anonymous, 2017, Indian horticulture database. www.nhb.gov.in.

Cheema, G.S. and Dani, P.C., 1934, Report on export of mangoes to Europe. Bulletin of Agricultural Department Bombay, pp. 17-18.

Corbesier, L., Bernier, G. and Perilleux, C. 2002, C:N ratio increases in the phloem sap during floral transition of the long-day plants, Sinapis alba and Arabidopsis thaliana. Plant Cell Physiol, 43: 684-688.

Davenport, T. L, Núñez-Elisea R. 1997, Reproductive physiology. In: Litz, R.E. (ed.) The Mango: Botany, Production and Uses. CAB International, Wallingford, Oxon, UK, pp. 69-146. Goguey, T., 1993, Study of effect of three flowering inducing substances on Kent and Zill mango. Acta Hort. 341: 216-224.

Kumar, M., Ponnuswami, V., Jeyakumar, P., Richard Kennedy R. and Saraswathy, S. 2013, Studies on influence of season for biochemical parameters in mango cultivars. African J. Agric. Res. 8(49) : 6394-6400.

Mukherjee, S. K. 1951, The origin of mango. Indian J. Genet., 2: 49.

Panse, V.G. and Sukhatme, P.V., 1985, Statistical methods for agricultural workers. Indian Council of Agricultural Research, New Delhi, pp.167-174.

Pathak, R. A. and Panday, R. M. 1978, Changes in he chemical composition of mango (Mangifera indica L.) leaves of 
cultivar Dashehari at different stages of flowering and fruit growth. Indian J. of Hort. 35: 309-314.

Patil, K. R. 2009, Studies on post harvest chemical induction of vegetative growth and its physiological behaviour in relation to regulation of flowering in Alphonso mango ((Mangifera indica L.). MSc. (Agri.) Thesis submitted to Dr. B. S. Konkan Krishi Vidyapeeth, Dapoli, Maharashtra, 415712.

Protacio, C.M. 2000, A model for potassium nitrate- induced flowering in mango. Acta Hort. 509: 545 -552.

Rakshe, M. V. 2011, Physiological studies on effect of stem girdling, root pruning and chemical treatments on induction of flowering in Alphonso mango (Mangifera indica L.). M. Sc. (Agri.) Thesis submitted to Dr. B. S. Konkan Krishi Vidyapeeth, Dapoli, Maharashtra 415712.
Ravishankar, H. and Rao, M. M. 1982, Studies on changes in Carbohydrate fractions and minerals in Alphonso mango shoots during pre and post fruit bud differentiation stages. $J$. Maharashtra Agric. Univ., 7(2): 143145.

Sarkar, D., Joon, M. S. and Bhatia, S. K. 2005, A note on bearing behavior of some new mango cultivars. Haryana $J$. Hort. Sci. 34(3-4): 300.

Sen, P.C. and Mallik, P.C. 1941, The time of differentiation of flower buds of the mango. Indian J. Agric. Sci., 11: 74-81.

Sudha, R., Balamohan, T. N. and Soorianathasundaram, K.. 2012, Effect of foliar spray of nitrogenous chemicals on flowering, fruit set and yield in mango (Mangifera indica L.) cv. Alphonso. J. Hort. Sci. 7(2): 190-193.

\section{How to cite this article:}

Malshe, K. V., S. S. Patil and Haldankar, P. M. 2020. Effect of Foliar Nutrients on Shoot Carbon and Nitrogen Content at Various Phenological Stages in Mango cv. Alphonso. Int.J.Curr.Microbiol.App.Sci. 9(01): 2475-2486. doi: https://doi.org/10.20546/ijcmas.2020.901.282 